\title{
Judaea-Palaestina, Babylon and Rome: Jews in Antiquity
}

\author{
Ed. by Benjamin Isaac and Yuval Shahar
}

[Judäa-Palästina, Babylon und Rom: Juden in der Antike.]

Judaea-Palaestina, Babylon and Rome: Jews in Antiquity

Edited by BENJAMIN ISAAC and YUVAL SHAHAR

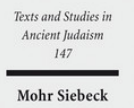

2012. IX, 324 Seiten. TSAJ 147

ISBN 978-3-16-152025-9

DOI 10.1628/978-3-16-152025-9

eBook PDF $114,00 €$

ISBN 978-3-16-151697-9

Leinen $114,00 €$
Veröffentlicht auf Englisch.

Der vorliegende Band vereint die Vorträge international renommierter Wissenschaftler der jüdischen Geschichte zur Zeit der Römer. Die meisten Beiträge wurden bei einer Konferenz an der Universität von Tel Aviv im Jahre 2009 zu Ehren von Aharon Oppenheimer vorgetragen. Der Band konzentriert sich auf bestimmte, klar abgegrenzte Themen in der Geschichte der Juden sowohl in Judäa als auch in der Diaspora: erstens auf das Bild, das Nicht-Juden von Juden und Juden von Nicht-Juden haben; dann auf Fragen der sozialen und geistigen Geschichte, hauptsächlich die, die sich mit den Veränderungen befassen, die als Ergebnis der gescheiterten jüdischen Aufstände gegen Rom stattfanden, sowie auf dringliche Aspekte der modernen Wissenschaft.

Die Studien befassen sich unter anderem mit der Beziehung sowie den kulturellen Unterschieden zwischen palästinensischen und babylonischen Juden; der Beziehung zwischen Juden und frühen Christen; der entstehenden Idee des Judentums des ersten Jahrhunderts, wie sie in frühen christlichen Quellen und der modernen Wissenschaft entworfen wird; der Rolle der Weisen zu dieser Zeit, der Konversion zum Judentum, dem jüdischen Widerstand sowie dem Märtyrertum unter der römischen Herrschaft.

Inhaltsübersicht

Benjamin Isaac / Yuval Shahar: Preface and Introduction

The Image of Jews among Non-Jews

Albert I. Baumgarten: The »Outreach« Campaign of the Ancient Pharisees: There is no such thing as a Free Lunch - Shaye J.D. Cohen: Dancing, Clapping, Meditating: Jewish and Christian Observance of the Sabbath in Pseudo-Ignatius

The Image of Non-Jews among Jews

Joshua Schwartz: How Jewish to be Jewish? Self-Identity and Jewish Christians in First Century CE Palestine - Günter Stemberger: The birkat ha-minim and the separation of Christians and Jews - Vered Noam: Another Look at the Rabbinic Conception of Gentiles from the Perspective of Impurity Laws - Richard Kalmin: The Evil Eye in Rabbinic Literature of Late Antiquity - Peter Schäfer: Jesus' Origin, Birth, and Childhood according to the Toledot Yeshu and the Talmud

\section{Social History}

Tessa Rajak: Reflections on Jewish Resistance and the Discourse of Martyrdom in Josephus - Martin Goodman: Titus, Berenice and Agrippa: the Last Days of the Temple in Jerusalem - Yuval Shahar: Why a quarter? The Siqariqon ruling and Roman Law - Susan Weingarten: How do you say haroset in Greek? - Jonathan J. Price: The Necropolis at Jaffa and its Relation to Beth She'arim - Youval Rotman: Captives and Redeeming Captives: the Law and the Community - Werner Eck: The Jewish Community in Cologne from Roman Times to the Early Middle Age

Issues in Modern Scholarship

David M. Goodblatt: The Jews in the Parthian Empire: What We Don't Know - Yoram Tsafrir : The Finds in Cave 2001-2002 and Burial at Masada - Isaiah Gafni : Will the 'Real' Rabbis Please Stand Up: On the Repackaging of the Rabbinic Model in Modern Times

Index

Aharon Oppenheimer's Publications

Benjamin Isaac Born 1945; immigrated to Israel in 1972; studied in Amsterdam, the Netherlands; currently Fred and Helen Lessing Professor of Ancient History, Tel Aviv University; member of the Israel Academy of Sciences and Humanities, Israel Prize Laureate.

Yuval Shahar Born 1953; studied Jewish History and Jewish Philosophy at Tel Aviv University; currently Senior Lecturer in the Department of Jewish History and Head of The Multidisciplinary Program in the Humanities, Tel Aviv University.

Jetzt bestellen:

https://mohrsiebeck.com/buch/judaea-palaestina-babylon-and-rome-jews-in-antiquity-9783161520259?no_cache=1 order@mohrsiebeck.com

Telefon: $+49(0) 7071-923-17$

Telefax: $+49(0) 7071-51104$ 